\title{
INCREASING THE LEVEL OF EDUCATIONAL SERVICES QUALITY IN HIGHER EDUCATION
}

\author{
ADAM STECYK \\ University of Szczecin, POLAND \\ e-mail: adam.stecyk@wzieu.pl
}

\section{RECEIVED \\ ACCEPTED \\ JEL \\ CLASSIFICATION \\ KEYWORDS}

ABSTRACT
26 April 2017

5 August 2017

$121,123,125,032$

quality, education, higher education, e-learning, ICT

The aim of the article is a presentation of the model of improving the educational quality service in higher education. Analysis was based on the model that uses: SERVPERF method testing the quality of service, a Likert scale and new framework tool that identifies the main factors determining the quality of a structural, methodical and social area in higher education. The proposed research concept can be used to analyze level of service within the framework of specific subjects, teaching staff and teaching modes, such as blended learning mode. Assuming a proper (the best description of the nature of education and quality) selection of descriptive characteristics and transforming them into real determinants of quality, the proposed concept can be used to improve the quality in other organizations. The main argument of the article assumes that maintaining and expanding a competitive advantage in the market of educational services in higher education, requires monitoring and flexibility in the implementation of both, proven technology and new, innovative educational tools, what leads to increased level of quality, usability and efficiency of distributed knowledge.

\section{Introduction}

The quality of educational services in higher education is increasingly effective tool to build competitive advantage in a rapidly changing economic environment. The development of the information society with the progressive processes of globalization and demographic change, as well as the growing importance of academic education, make it necessary to adapt the Polish universities to the challenges of the twenty-first century. The article 
discusses the issues of pro-quality approach to the polish universities, in the context of ongoing changes in the methodology of training, technological development, the development of functional and organizational models and social changes in relation to higher education. The primary purpose of the article was to identify and analyze the key factors responsible for the level of quality in higher education.

\section{Structural, functional and social aspects of higher education}

The starting point for in-depth analysis of the problem was the adoption of a number of methodological assumptions, allowing the use of certain elements of the analytical methods [system-based approach - the structural aspects (Bertalanffy, 1968), (Sadowski, 1978), process - functional aspects (Hammer, 1999) and the theory of stakeholders - social aspects (Pajunen, 2002)] to describe the pro-quality problems at the academic level. The most important of them include:

1. The university (or intentionally separate unit, for example, a department) as an institution of public trust, fulfills a certain social mission and seeks to achieve the desirable level of quality of educational services, through rational configuration of resources and proper processes coordination.

2. The university is an object that can be analyzed in terms of structure (configuration resources) and functionality (coordination processes), and can be divided into five basic areas: organizational, economic, infrastructural, social and methodical.

3. Identification of key elements that determine the quality of educational services on separate five areas allow to improve quality and give an answer to the question about the directions of qualitative changes in higher education.

Separation of these five areas (Figure 1) is contractual in nature and is used to better understand the qualitative aspects of ongoing education services. ${ }^{1}$ In business practice the selected areas penetrate each other, and their key resources and processes create a network of mutual ties and interaction.

Scientific literature, that describes the method of improving the level of quality services, shows that the most commonly used approach is to adopt the customer's perspective and assessment of the satisfaction with the service received (Bryman, 1998; Payson, 1994). In the case of educational services, the key is therefore to develop such a test method that will enable analysis of the presented determinants of quality, as well as their impact (according to the respondents) or the impact of individual areas on the quality of service within a timeframe for a certain academic organization.

Developing a consistent mechanism to improve the quality of educational services in higher education is a complex and complicated task. This is mainly due to the basic features of educational services (immateriality, impermanence, heterogeneity, inseparability, individuality, etc.), hence the assessment of the level of quality is very subjective.

${ }^{1}$ In the literature one can find different theoretical models of quality services, such as: Service Quality Model (Grönroos, 1984) or Gummesson's partial quality model (Gummesson, 1996), but this approach is based on SERVQUAL and SERVPERF models (Parasuraman, Zeithaml, Berry, 1994). 


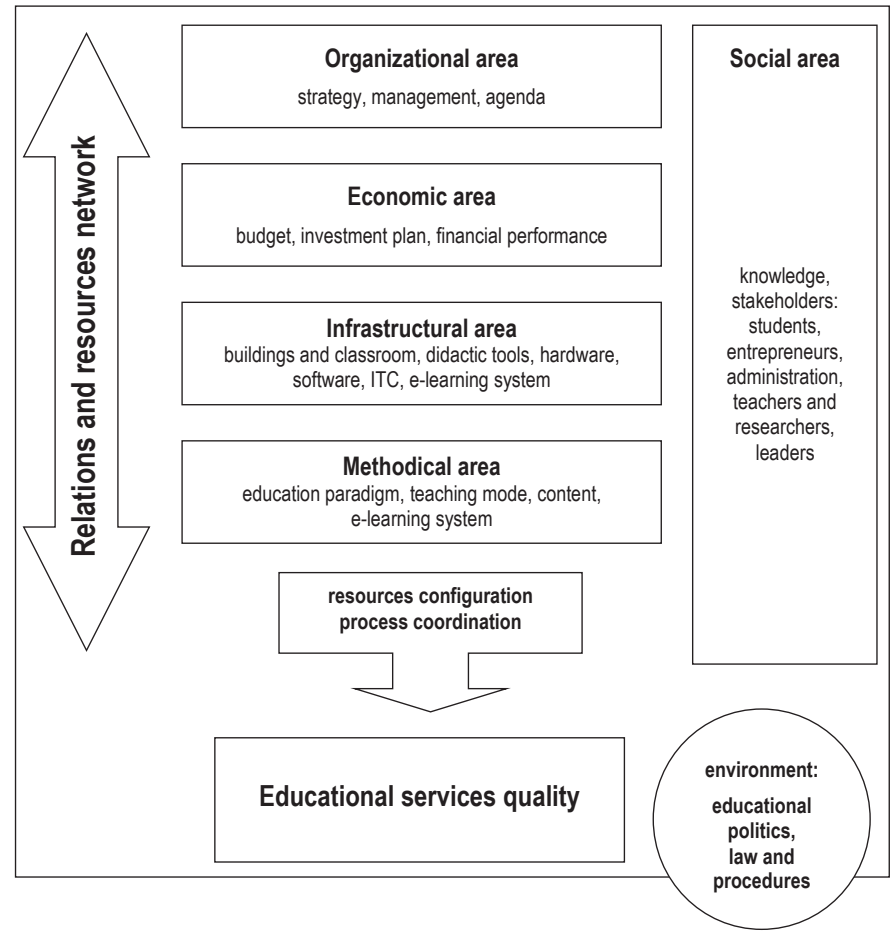

Figure 1. Schematic diagram of the educational services quality in higher education

Source: own study.

In the literature on the study of socio-economic problems, one of the major divisions of methods of analyzing problems is the division into quantitative and qualitative methods. Apart from the details of the academic dispute over the "superiority" of one method over another, it should be stated that the choice of the way of analyzing processes and/or objects should be conditioned by the essence and subject of the phenomenon under investigation. There are no better or worse methods, they are only better or worse adapted to the analysis, interpretation and understanding of specific socio-economic phenomena. "Every good researcher knows that the choice of method should not be imposed in advance. You should rather choose a method that corresponds to what the researcher wants to know" (Silverman, 2009).

\section{Methods of improving the quality of educational services}

When analyzing the literature on the problems of improving the quality of services one will find that some of the most commonly used methods (or their modified versions) are the SERVQUAL (Parasuraman, Zeithaml, Berry, 1994) and SERVPERF methods.

SERVQUAL method refers to a model of service quality developed by A. Parasuraman, V. Zeithaml and L.L. Berry, also called the model of gaps (GAPS model) (Rudawska, Kiecko, 2000). It refers to the fifth and final gap, which is characterized by differences between the expectations of stakeholders, and the actual perception of the product or service. 
In the nineties of the twentieth century, a team of two scientists J.J. Cronin and A. Taylor suggested a significant modification of the SERVQUAL method. The authors of a new concept assumed that the essence of the analysis of the service quality is a subjective assessment of the customers' opinions after service is delivered, however, they ruled out the necessity of examining the quality level of expected service (before it is delivered), assuming that the customer will always expect quality at the highest level. The new method was called SERVPERF (service performance) and may be considered as a counter-proposal to the SERVQUAL method (Cronin, Taylor, 1994).

\section{The model of improving the educational services quality in higher education}

The main problem of testing the level of quality of educational services was to identify the key factors for quality in five separate areas of the analyzed organization. Respondents made the analysis of all proposed determinants, and their comments, suggestions and observations were taken into account in the further stages of research. In this way, the original list of 46 was limited to 32 items. A detailed list of factors determining the level of quality of educational services is presented in Table 1.

Table 1. List of the determinants of the quality of educational services at selected areas

\begin{tabular}{|c|c|}
\hline 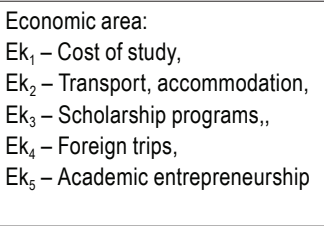 & $\begin{array}{l}\text { Organizational area: } \\
\mathrm{Ok}_{1}-\text { Time implementation activities } \\
\mathrm{Ok}_{2}-\text { Consultations and lectures on-line, } \\
\mathrm{Ok}_{3}-\text { Administrative procedures, } \\
\mathrm{Ok}_{4}-\text { Student activities, } \\
\mathrm{Ok}_{5}-\text { Job fairs, } \\
\mathrm{Ok}_{6}-\text { Foreign language studies }\end{array}$ \\
\hline 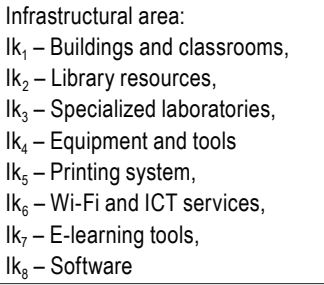 & $\begin{array}{l}\text { Methodical area: } \\
\mathrm{Mk}_{1} \text { - Content, } \\
\mathrm{Mk}_{2} \text { - Teaching efficiency, } \\
\mathrm{Mk}_{3} \text { - Teaching mode, } \\
\mathrm{Mk}_{4} \text { - Presentation tools, } \\
\mathrm{Mk}_{5} \text { - Communication tools, } \\
\mathrm{Mk}_{6} \text { - Verification tools, } \\
\mathrm{Mk}_{7} \text { - Innovative solutions, } \\
\mathrm{Mk}_{8} \text { - Mobile solutions }\end{array}$ \\
\hline $\begin{array}{l}\text { Social area: } \\
\mathrm{Sk}_{1}-\text { Knowledge, } \\
\mathrm{Sk}_{2} \text { - Skill transfer, } \\
\mathrm{Sk}_{3} \text { - Ethics and manners, } \\
\mathrm{Sk}_{4} \text { - Practice, } \\
\mathrm{Sk}_{5} \text { - Prestige }\end{array}$ & \\
\hline
\end{tabular}

Source: own studies.

The research was conducted on a sample of 321 students of the Faculty of Management and Economics of Services (University of Szczecin, Poland) in the academic year 2014/2015 (winter semester 2014 and spring semester 2015). The sample selection was random. Preliminary analysis of presented characteristics shows that the study was attended by both bachelor and master students (69\% and $31 \%)$. Most respondents were female $(61 \%$, men $39 \%$ ) and residents of Szczecin (69\%, 31\% of outsiders). The collected empirical data related to the quality problems, allowed the use of statistical analysis to aggregate information and calculate the average value of the results for the five specified areas (Table 2). 
Table 2. Average rating of selected areas

\begin{tabular}{lcc}
\hline \multicolumn{1}{c}{ Area } & Rating & Importance (\%) \\
\hline Economic & 5.04 & 18.3 \\
Organizational & 4.08 & 19.7 \\
Infrastructural & 4.69 & 18.5 \\
Methodical & 4.19 & 22.1 \\
Social & 4.91 & 21.4 \\
\hline Average & 4.58 & $\mathrm{X}$ \\
\hline
\end{tabular}

Source: own study.

Most valued group of factors is the economic area (5.04), which also has been classified as the least important for quality matters among the remaining areas (18.3\%). In the second place were the factors grouped on the social area (average score 4.91), while the weight of the social dimension was $21.4 \%$ (second in importance). Infrastructural area has been assessed at the level of 4.69, and its weight (importance) was 18.5\%. A little below, the students evaluated the factors determining the quality of a methodical area (4.19), while the weight of this group of factors has been recognized as the highest and stood at $22.1 \%$. The lowest value was assessed at organizational level (4.08), while the weight of this dimension was $19.7 \%$.

Detailed analysis of partial results concerning the specific factors determining the level of quality at selected five areas are beyond the scope of this article. However, studies made it possible to note that the final level of evaluation of the quality of educational services was essentially influenced by three groups of factors: ${ }^{2}$

- the factors determining the satisfactory level of quality,

- the factors determining the acceptable level of quality,

- the factors determining the unsatisfactory level of quality.

Summary of all the elements allowed to create so-called determinants map of quality, which shows the possible ways of specific, required corrective actions. Factors that for objective reasons cannot be adapted to the requirements of service users, should be subject to discussion among the leaders of the department, and specific changes should be included in the strategic and tactical documents concerning development (for example, radical cost reduction, cannot be implemented in the short period of time, but strategy for scholarships can be discussed and included in development strategy of the organization).

There are 11 items among the factors which quality level is defined as unsatisfactory (Table 3), 4 of which relate to the methodical dimension, 3 to infrastructural, 2 to organizational and 1 to both economic and social. Assuming that due to financial, infrastructural and time limitations, the adaptation program cannot be focused on 4 factors (printing system, mobile tools, software and innovation tools) the remaining 8 determinants may be a subject to certain modifications, which may lead to increase the level of quality of educational services in the near future.

2 The scale uses the following assumptions: a range of values from 1 to 4.5 - the factors determining the unsatisfactory level of quality; 4-5 - acceptable and 5 or more - satisfactory. However, due to several key factors, specific determinants have been "manually" shifted to a different group when their values were close to the borders of scale ranges. 
Table 3. The factors determining the unsatisfactory level of quality

\begin{tabular}{rlrl}
\hline No. & \multicolumn{1}{c}{ Determinant } & Value & \multicolumn{1}{c}{ Area } \\
\hline 1. & Consultations and lectures on-line & 2.48 & Organizational \\
2. & Printing system & 2.51 & Infrastructural \\
3. & Foreign language studies & 2.65 & Organizational \\
4. & Mobile solutions & 2.87 & Methodical \\
5. Innovative solutions & 2.93 & Methodical \\
6. & E-learning tools & 3.32 & Infrastructural \\
7. & Software & 3.90 & Infrastructural \\
8. & Communications tools & 4.12 & Methodical \\
9. & Practice & 4.16 & Social \\
10. & Academic entrepreneurship & 4.20 & Economic \\
11. & Verification tools & 4.32 & Methodical \\
\hline
\end{tabular}

Source: own studies.

The analysis show another group of factors whose quality level was found to be admissible (Table 4), but they still require a specific adjustment.

Table 4. The factors determining the acceptable level of quality

\begin{tabular}{clcl}
\hline No. & \multicolumn{1}{c}{ Determinant } & Value & \multicolumn{1}{c}{ Area } \\
\hline 1. & Presentation tools & 4.55 & Methodical \\
2. & Administrative procedures & 4.73 & Organizational \\
3. & Teaching efficiency & 4.75 & Methodical \\
4. & Job fairs & 4.76 & Organizational \\
5. & Time implementation activities & 4.83 & Organizational \\
6. & Teaching mode & 4.85 & Methodical \\
\hline
\end{tabular}

Source: own studies.

Of course, a change in the paradigm of education, related to the appropriate choice of teaching mode, and increasing the level of effectiveness in knowledge transfer takes time and requires great deal of experience. Sometimes it takes not only a big changes in the perception of the teacher's and student's role in the didactic process, but also the commitment and determination of academics and administration workers in all the organizational and administrative process.

The last and the largest group of items are determinants of a satisfactory level (which does not mean the optimum level of quality, Table 5 . Most determinants are grouped at infrastructure area ( 5 items) and then, economic ( 4 items), social ( 4 items) and methodical ( 1 factor). This result means that these factors, grouped on the least flexible areas (due to financial, organizational, infrastructural limitations) has been assessed positively. This indicates that the largest potential in increasing the level of service quality may take place through changes in the methodical and organizational area. 
Table 5. The factors determining the satisfactory level of quality

\begin{tabular}{rlll}
\hline No. & \multicolumn{1}{c}{ Determinant } & Value & \multicolumn{1}{c}{ Area } \\
\hline 1. & Transport and accommodation & 4.80 & Economic \\
2. & Equipment & 4.80 & Infrastructural \\
3. & Skill transfer & 4.90 & Social \\
4. & Prestige & 4.95 & Social \\
5. & Content & 5.06 & Methodical \\
6. & Student activities & 5.10 & Organizational \\
7. & Ethics and manners & 5.19 & Social \\
8. & Scholarship programs & 5.20 & Economic \\
9. & Knowledge & 5.30 & Social \\
10. & Buildings and classroom & 5.39 & Infrastructural \\
11. & Foreign trips & 5.40 & Economic \\
12. & Study cost & 5.60 & Economic \\
13. & Specialized laboratories & 5.75 & Infrastructural \\
14. & Wi-Fi and ICT services & 5.86 & Infrastructural \\
15. & Library resources & 5.90 & Infrastructural \\
\hline
\end{tabular}

Source: own studies.

\section{Conclusions}

The study ends a phase of analyzing the possibilities of improving the quality of educational services in selected organization. This raises the question about the possibility of using the proposed model for other educational entities. The answer to that problem is not simple, because it depends on the individual nature of certain academic units, their specificity, technological capacity and human resources, as well as strategy development. One can, however, be noted that assuming proper (that is, the best possible description of the nature and essence of education and quality) selection of descriptive characteristics and transforming them into real determinants of quality, the proposed concept can be used to improve the quality of other academic organizations. This also applies to universities with different structure and profile than the one analyzed and studied in this paper (Faculty of Economics and Management of Services). Of course, a modified quality model for new academic organizations will take into account these elements, which play a key role in their educational operations; in particular, the new areas and identified determinants may be added or removed to/from the proposed model. In other words, the individual character of each institution, allows the use of the proposed concept to improve the quality of educational services, including adjustments for details corresponding to the structure and operation of the particular organizations. The universal nature of the proposed approach can be used on several levels:

Level I - Evaluation of selected subjects by the teacher specified period of time.

Level II - Evaluation and comparison of specific groups (subjects, teachers, students, teaching modes, tools, etc.).

Level III - evaluation of the quality of educational services within the whole organization (for example, at the university), through periodic studies and comparing the results in the context of separate areas and specific quality factors. 
Level IV - comparison of two (or more) higher education institutions, with the following assumptions: 1. The universities or isolated unit (faculty) should have similar profile and structure 2 . The list of determinants must be the same for all analyzed organizations and the study must be carried out by external evaluation center (e.g. a specific group of experts).

Summing up the previous considerations, it should be emphasized once again that the problem of studying the quality in higher education, and in particular the proper identification of the determinants of the quality of services, their selection and evaluation, are a challenge for all the academic organizations. Based on studies of literature, analysis of the available models and qualitative methods, the article shows the original concept that allows the assessment of quality issues in education at the university level. Results of this study indicate the need of individual approach to the studied organization so that the proposed five-areas model and proposed determinants are the best way to capture the essence of the quality of education services in higher education.

\section{References}

Bertalanffy, L. v. (1968). General System Theory: Foundations, Development, Applications. New York : George Braziller.

Bryman, A. (1998). Quantity and Quality In Social Research. Londyn: Unwin Hyman.

Cronin, J., Taylor, S. (1994). SERPVERF Versus SERVQUAL: Reconciling Performance-Based and Perceptions - Minus-Expectations Measurement of Service quality. Journal of Marketing, 1 (58), 23-24.

Grönroos, C. (1984). A Service Quality Model and Its MarketingImplications. European Journal of Marketing, 4 (18).

Gummesson, E. (1996). Quality Management In Service Organizations. ISQA.

Hammer, M. (1999). Reinżynieria i jej następstwa. Warszawa: Wydawnictwo Naukowe PWN.

Pajunen, K. (2002). A stakeholder Framework for Analysis of Inter-organizational relationship in a crisis situation: A historical case study illustration. Helsinki: EBHA, Annual Congress.

Parasuraman, A., Zeithaml, V., Berry, L. (1994). Alternative scales for measuring service quality: A comparative assessment based on psychometric and diagnistic criteria. Journal of Marketing, 3 (70), 201-230.

Payson, S. (1994). Quality Measurement in economics. New Perspectives on the Evolution of Goodsand Services. Londyn: E.E.Publishing Company.

Rudawska, E., Kiecko, R. (2000). SERVQUAL - metoda badania jakości usług i jej praktyczne zastosowanie. Marketing i Rynek, 5 , 12-13.

Sadowski, W. (1978). Podstawy ogólnej teorii systemów. Warszawa: PWN.

Silverman, D. (2009). Prowadzenie badań jakościowych. Warszawa: Wydawnictwo Naukowe PWN.

Tijssen, R.J. (1998). Quantitative Assessment of Large Heterogeneous R\&D Networks: The Case of Process Engineering in the Netherlands. Research Policy, 26, 7-8.

Cite this article aS: Stecyk, A. (2017). Increasing the level of educational services quality in higher education. European Journal of Service Management, 3 (23), 71-78. DOI: 10.18276/ejsm.2017.23-09. 